\title{
PENINGKATAN KEMAMPUAN GURU PENDIDIKAN AGAMA ISLAM DALAM PENYUSUNAN RENCANA PELAKSANAAN PEMBELAJARAN MELALUI MUSYAWARAH GURU MATA PELAJARAN (MGMP) TAHUN PELAJARAN 2016/2017 KABUPATEN BARITO KUALA
}

\author{
M. Riduan \\ Kementerian Agama Kabupaten Barito Kuala \\ E-mail: mriiduan@gmail.com
}

\begin{abstract}
Forum of subject teachers is series of activities to help teachers develop their abilities to manage learning process for reaching of learning objectives. This research aims to improve Islamic Education teachers's ability for preparing Lesson Plan. The type of the research is Action Research in school that used two cycles. The subjects of this research are 23 Islamics Education teachers in Barito Kuala at 2016/2017 academic year. The results showed that implementation forum of Islamic Eduaction teachers can help improve teachers's ability to prepare Lesson Plan.
\end{abstract}

Keywords: action research, forum of teachers, lesson plan

\begin{abstract}
ABSTRAK
Musyawarah guru mata pelajaran adalah serangkaian kegiatan membantu guru mengembangkan kemampuannya mengelola proses pembelajaran demi pencapaian tujuan pembelajaran. Penelitian ini bertujuan untuk meningkatkan kemampuan guru Pendidikan Agama Islam dalam menyusun Rencana Pelaksanaan Pembelajaran (RPP). Penelitian ini merupakan Penelitian Tindakan Sekolah (PTS) yang dilaksanakan dalam 2 siklus. Subyek penelitian ini adalah guru-guru Pendidikan Agama Islam Kabupaten Barito Kuala pada tahun pelajaran 2016/2017 sebanyak 23 orang. Hasil penelitian ini menunjukkan bahwa pelaksanaan kegiatan musyawarh guru mata pelajaran dapat membantu meningkatkan guru Pendidikan Agama Islam dalam menyusun RPP.
\end{abstract}

Kata Kunci: penelitian tindakan sekolah, musyawarah guru mata pelajaran, rencana pelaksanaan pembelajaran 


\section{PENDAHULUAN}

Guru idealnya selalu tampil secara profesional dengan tugas utamanya adalah mendidik, membimbing, melatih, dan mengembangkan kurikulum (perangkat kurikulum), sebagaimana bunyi prinsip "ing ngarso sung tulodo, ing madya mangun karso, tut wuri handayani." Artinya seorang guru bila di depan memberikan suri tauladan (contoh), di tengah memberi prakarsa dan dibelakang memberikan dorongan atau motivasi (Rusman, 2013: 15). Hasil penelitian yang dilakukan oleh Riduan (2017) menunjukkan bahwa kemampuan guru PAI harus ditingkatkan agar kualitas pembelajaran dalam kelas juga lebih baik lagi. Peningkatan kemampuan guru bisa dengan melalui forum guru (MGMP), pelatihan penggunaan media, pelatihan penyusunan RPP.

Keberadaan Musyawarah Guru Mata Pelajaran ( MGMP) merupakan suatu wadah asosiasi atau perkumpulan bagi guru mata pelajaran yang berada di suatu sanggar, kabupaten/kota yang berfungsi sebagai sarana untuk saling berkomunikasi, belajar, dan bertukar pikiran dan pengalaman dalam rangka meningkatkan kinerja guru sebagai praktisi/pelaku perubahan reorientasi pembelajaran di kelas. Organisasi ini bersifat mandiri dan terbuka bagi semua guru mata pelajaran baik yang berstatus pegawai negeri sipil, guru tidak tetap, dan guru pada sekolah swasta yang berada dilingkungan wilayah kabupaten/kota.

MGMP Pendidikan Agama Islam salah satunya dibentuk untuk berpartisipasi membantu peningkatan kualitas pendidikan di Kabupaten Barito Kuala pada umumnya dan meningkatkan kinerja guru mata pelajaran Pendidikan Agama Islam yang siap pakai sesuai dengan perubahan paradigma pendidikan di era globalisasi pada khususnya. Dalam pelaksanaanya MGMP Pendidikan Agama Islam Kabupaten Barito Kuala mengacu pada roh kegiatan sesuai dengan fungsi dan program kegiatan.

Kompetensi supervisi akademik merupakan pembinaan guru dalam meningkatkan mutu proses pembelajaran. Sasaran supervisi akademik adalah guru dalam melaksanakan proses pembelajaran, yang terdiri dari materi pokok dalam proses pembelajaran, penyusunan silabus dan RPP, pemilihan strategi/metode/ teknik pembelajaran, penggunaan media dan teknologi informasi dalam pembelajaran, menilai proses dan hasil pembelajaran serta penelitian tindakan kelas (Kemdiknas, 2010b : 6). Tujuan supervisi akademik dalam Glickman, et al; 2007, Sergiovanni, 1987 sebagaimana dituliskan Kemdiknas (2010b : 7) adalah:

1. membantu guru mengembangkan kompetensinya,

2. mengembangkan kurikulum,

3. mengembangkan kelompok kerja guru, dan membimbing penelitian tindakan kelas (PTK).

Kemdiknas (2010b: 8) menyatakan bahwa hasil supervisi akademik berfungsi sebagai sumber informasi bagi pengembangan profesionalisme guru.

Kenyataan yang ditemukan bahwa ada permasalahan bagi guru dalam menyusun Rencana Pelaksanaan Pembelajaran (RPP). Menurut Depdiknas (2007a : 162) dalam Buku Materi Sosialisasi dan pelatihan Kurikulum Tingkat Satuan Pendidikan (KTSP) dijelaskan Rencana Pelaksana Pembelajaran (RPP) adalah rencana yang menggambarkan prosedur dan pengorganisasian pembelajaran untuk mencapai suatu kompetensi dasar yang ditetapkan dalam Standar isi dan telah dijabarkan dalam silabus. Lingkup Rencana Pembelajaran paling luas mencakup 1 (satu) kompetensi dasar yang terdiri dari 1 (satu) atau beberapa indikator untuk 1 (satu) kali pertemuan atau lebih.

Pada umumnya guru hanya menyadur kepunyaan orang lain, hanya 
sebagian kecil guru yang membuat RPP sendiri. Permasalahan ini besar kemungkinan disebabkan oleh:

1. Kurang meratanya sosialisasi (Diklat) mengenai penyusunan PPP dan dari Dinas Pendidikan maupun Kementerian Agama.

2. Belum adanya pelaksanakan bimbingan khusus kepada guru-guru PAI dalam menyusun RPP.

3. Alasan klasik yakni malas, sibuk dan tidak menguasai TIK.

Dengan melihat permasalahan seperti tersebut di atas, peneliti tertarik untuk melakukan penelitian tindakan sekolah dengan judul "Peningkatan Kemampuan Guru Pendidikan Agama Islam dalam Penyusunan Rencana Pelaksanaan Pembelajaran melalui Musyawarah Guru Mata Pelajaran Tahun Pelajaran 2016/2017 Kabupaten Barito Kuala".

\section{METODE PENELITIAN}

Penelitian ini dilaksanakan di Kabupaten Barito Kuala Provinsi Kalimantan Selatan selama 4 bulan, selama bulan Agustus sampai dengan November 2016. Guru Pendidikan Agama Islam yang diteliti berjumlah 23 orang, berstatus Pegawai Negeri Sipil (PNS) dan non PNS.

Penelitian ini merupakan penelitian tindakan sekolah dengan langkah-langkah: perencanan, pelaksanaan, pengamatan, dan refleksi. Penelitian ini direncanakan terdiri dari dua siklus.

Data diambil dan dikumpulkan menggunakan lembar atau instrumen penilaian RPP. Analisis data kuantitatif digunakan untuk mengetahui peningkatan nilai praktik pembuatan RPP oleh guru berdasarkan standar yang telah ditetapkan Depdiknas seperti dikutip Zainal Aqib (2009 : 48 sebagai berikut (Tabel 1) :
Tabel 1. Rentang Kategori Nilai Pembuatan RPP

\begin{tabular}{lll}
\hline No. & Nilai & Kategori \\
\hline 1. & $91-100$ & $\begin{array}{l}\text { Amat baik (A), Amat } \\
\text { berhasil }\end{array}$ \\
\hline 2. & $76-90$ & Baik (B), berhasil \\
\hline 3. & $55-75$ & $\begin{array}{l}\text { Cukup (C), belum } \\
\text { berhasil }\end{array}$ \\
\hline 4. & $0-54$ & $\begin{array}{l}\text { Kurang (D), belum } \\
\text { berhasil }\end{array}$ \\
\hline
\end{tabular}

Data yang terkumpul digunakan untuk menilai keberhasilan tindakan dengan indikator keberhasilan berupa peningkatan nilai lembar observasi Rencana Pelaksanaan Pembelajaran (RPP) pada dua siklus yang dilaksanakan. Adapun nilai indikator keberhasilan perorangan dalam lembar penilaian Rencana Pelaksanaan Pembelajaran (RPP) adalah 80.

\section{HASIL DAN PEMBAHASAN}

\section{A. Hasil Penelitian}

Kabupaten Barito Kuala Provinsi Kalimantan Selatan memiliki 17 (tujuh belas) kecamatan. Sebagian besar kecamatan sudah memiliki SMA, dan sebagian kecil SMK. Sekolah Menengah Atas Negeri (SMAN) ada 13 buah, dan satu swasta serta tiga buah SMKN. Proses belajar mengajarnya dimulai 07.30-14.00 WITA, pada hari Jum'at kegiatan belajar untuk seluruh siswa berakhir pukul 10.40 WITA.

Dari 23 orang guru Pendidikan Agama Islam yang menjadi objek penelitian ini, sebagian besar belum menguasai penyusunan Rencana Pelaksanaan Pembelajaran. Hal ini mungkin disebabkan kurang meratanya sosialisasi (Diklat) mengenai penyusunan PPP, belum adanya pelaksanakan bimbingan khusus kepada guru-guru PAI dalam menyusun RPP dari Dinas Pendidikan maupun Kementerian Agama, serta alasan klasik berupa malas, sibuk dan lain sebagainya. Tabel 2 menunjukkan skor pencapaian nilai RPP masing-masing guru. 
Jurnal PTK dan Pendidikan

Vol. 3 No. 2. Juli - Desember 2017 (11-18)

Tabel 2. Skor Penilaian RPP

\begin{tabular}{cccc}
\hline Nama & Asal & Nilai & Ketercapaian \\
\hline M. Adnan Fahrani & SMAN I Mandastana & 80 & - \\
\hline Mansyah & SMAN I Marabahan & 90 & - \\
\hline M. Gazali & SMAN I Anjir Muara & 92,5 & $\vee$ \\
\hline Rahyono & SMAN I Alalak & 92,5 & $\vee$ \\
\hline Hildayati & SMAN I R. Badauh & 92,5 & $\vee$ \\
\hline Arbayah & SMAN I Tabukan & 87,5 & - \\
\hline Zakiyah & SMAN I Tabunganen & 87,5 & - \\
\hline Aspul & SMAN I Tabukan & 90 & - \\
\hline Fauriah & SMKN I Marabahan & 92,5 & $\vee$ \\
\hline Muzdalifah & SMKN I Marabahan & 90 & - \\
\hline Badiyah & SMAN I Marabahan & 87,5 & - \\
\hline Hj. Hamsiah & SMAN I Marabahan & 92,5 & - \\
\hline Mursyidi & SMAN I Mekarsari & 80 & - \\
\hline Fahrujjaini & SMAN I Belawang & 85 & - \\
\hline Syahdani & SMKN 2 Marabahan & 80 & - \\
\hline Juhri & SMAN I Alalak & 87,5 & - \\
\hline H.Mhammad Amin & SMA GIBs & 87,5 & - \\
\hline M. Abdul Kadir & SMAN I Bakumpai & 87,5 & - \\
\hline Norhadi & SMAN I Wanaraya & 87,5 & - \\
\hline Miftahul Arifin & SMAN I Wanaraya & 80 & $\vee$ \\
\hline Aidawati & SMAN I Anjir Pasar & 92,5 & - \\
\hline Khairiah & SMAN I Tamban & 92,5 & 87,5 \\
\hline Sumarli & SMAN I Tamban & & \\
\hline
\end{tabular}

Keterangan : $\vee$ : Tercapai; - : Tidak tercapai

Berdasarkan data di atas tercatat bahwa hanya 7 orang guru Pendidikan Agama Islam yang mencapai nilai, yang artinya baru 30,34\% guru yang mencapai nilai inidikator keberhasilan penyusunan RPP. Maka dari itu, dilakukan tindakan untuk peningkatan skor ketercapaian melalui siklus I dan II.

\section{Siklus 1}

\section{Perencanaan}

Pada fase perencanaan siklus I ini kegiatan yang dilaksanakan yaitu :

a. Mempersiapkan instrument observasi penilaian RPP.

b. Merencanakan tindakan siklus I akan dilaksanakan pada minggu ke-4 Oktober 2016.

c. Merencanakan tempat pelaksanaan tindakan.

d. Mempersiapkan fasilitas yang digunakan berupa lembar observasi, alat-alat tulis dan alat-alat dokumentasi, serta ruang pelaksanaan observasi tindakan.
2. Pelaksanaan

Langkah-langkah pelaksanaan tindakan siklus I yaitu :

a. Memilih alat observasi sesuai nama guru yang diobservasi, karena lembar observasi telah diberi nama terlebih dahulu.

b. Melaksanakan supervise akademik/ observasi RPP.

c. Memberi saran-saran perbaikan pembuatan RPP berikutnya, dan memberi penguatan bagi guru yang telah memiliki kemampuan pembuatan RPP yang baik.

3. Hasil Pelaksanaan

Pelaksanaan tindakan supervise akademik penyusunan RPP pada siklus I ini menghasilkan data Tabel 3. 
Tabel 3. Hasil Penilaian RPP Siklus I

\begin{tabular}{lcc}
\hline Nama Guru PAI & Nilai & $\begin{array}{c}\text { Keterca } \\
\text { paian }\end{array}$ \\
\hline M. Adnan Fahrani & 80 & - \\
\hline Mansyah & 92,5 & $\mathrm{~V}$ \\
\hline M. Gazali & 95 & $\mathrm{~V}$ \\
\hline Rahyono & 92,5 & $\mathrm{~V}$ \\
\hline Hildayati & 92,5 & $\mathrm{~V}$ \\
\hline Arbayah & 87,5 & - \\
\hline Zakiyah & 92,5 & $\mathrm{~V}$ \\
\hline Aspul & 92,5 & $\mathrm{~V}$ \\
\hline Fauriah & 92,5 & $\mathrm{~V}$ \\
\hline Muzdalifah & 92,5 & $\mathrm{~V}$ \\
\hline Badiyah & 92,5 & $\mathrm{~V}$ \\
\hline Hj. Hamsiah & 92,5 & $\mathrm{~V}$ \\
\hline Mursyidi & 80 & - \\
\hline Fahrujjaini & 92,5 & $\mathrm{~V}$ \\
\hline Syahdani & 80 & - \\
\hline Juhri & 92,5 & $\mathrm{~V}$ \\
\hline Muhammad Amin & 87,5 & - \\
\hline M. Abdul Kadir & 92,5 & $\mathrm{~V}$ \\
\hline Norhadi & 92,5 & $\mathrm{~V}$ \\
\hline Miftahul Arifin & 85 & - \\
\hline Aidawati & 92,5 & $\mathrm{~V}$ \\
\hline Khairiah & 92,5 & $\mathrm{~V}$ \\
\hline Sumarli & 92,5 & $\mathrm{~V}$ \\
\hline Keterangan : $\mathrm{V}:$ Tercapai; & \\
\hline
\end{tabular}

\section{Refleksi}

Berdasarkan Tabel 3 dapat diambil refleksi bahwa 17 orang atau 73,91\% guru Pendidikan Agama Islam sudah dapat membuat RPP dengan cukup baik. Kriteria cukup baik disini berarti penyusunan RPP guru yang bersangkutan telah mencapai rentang nilai 55 - 75 . Sedangkan 6 orang atau 26,9\% lagi belum berhasil mencapai criteria keberhasilan, artinya penyusunan RPP yang bersangkutan belum mencapai rentang nilai 91-100.

Dengan data yang didapat seperti diuraikan di atas, tentu diperlukan tindakan siklus II untuk meningkatkan kemampuan guru dalam menyusun RPP, sehingga diharapkan guru Pendidikan Agama Islam dapat mencapai rentang nilai minimal 91-100.

\section{Siklus II}

\section{Perencanaan}

Pada fase perencanaan siklus I ini kegiatan yang dilaksanakan yaitu :

a. Mempersiapkan instrument observasi penilaian RPP,

b. Merencanakan tindakan siklus I akan dilaksanakan pada minggu pertama November 2016.

c. Merencanakan tempat pelaksanaan tindakan akan dilaksanakan.

d. Mempersiapkan fasilitas yang digunakan berupa lembar observasi, alat-alat tulis dan alat-alat dokumentasi, serta ruang pelaksanaan observasi tindakan.

2. Pelaksanaan

Langkah-langkah pelaksanaan tindakan siklus II yaitu :

a. Memilih alat observasi sesuai nama guru yang diobservasi, karena lembar observasi telah diberi nama terlebih dahulu

b. Melaksanakan supervisi akademik atau observasi RPP

c. Memberi saran-saran perbaikan pembuatan RPP berikutnya,

d. Memberi penguatan bagi guru yang telah memiliki kemampuan pembuatan RPP yang baik.

3. Hasil Pelaksanaan

Pelaksanaan tindakan supervisi akademik penyusunan RPP pada siklus II ini menghasilkan data sebagai berikut (Tabel 4) :

\section{Tabel 4. Hasil Penilaian RPP Siklus II}

\begin{tabular}{lcc}
\hline Nama Guru PAI & Nilai & $\begin{array}{c}\text { Keter } \\
\text { Capaian }\end{array}$ \\
\hline M. Adnan Fahrani & 92,5 & $\vee$ \\
\hline Mansyah & 92,5 & $\vee$ \\
\hline M. Gazali & 95 & $\vee$ \\
\hline Rahyono & 92,5 & $\vee$ \\
\hline Hildayati & 92,5 & $\vee$ \\
\hline Arbayah & 87,5 & $\vee$ \\
\hline Zakiyah & 92,5 & $\vee$ \\
\hline Aspul & 92,5 & $\vee$ \\
\hline Fauriah & 95 & $\vee$ \\
\hline Muzdalifah & 92,5 & $\vee$ \\
\hline Badiyah & 92,5 & $\vee$ \\
\hline Hj. Hamsiah & 95 & $\vee$ \\
\hline
\end{tabular}




\begin{tabular}{lcc}
\hline Mursyidi & 87,5 & - \\
\hline Fahrujjaini & 92,5 & $\vee$ \\
\hline Syahdani & 92,5 & $\vee$ \\
\hline Juhri & 92,5 & $\vee$ \\
\hline Muhammad Amin & 90 & - \\
\hline M. Abdul Kadir & 92,5 & $\vee$ \\
\hline Norhadi & 92,5 & $\vee$ \\
\hline Miftahul Arifin & 92,5 & $\vee$ \\
\hline Aidawati & 92,5 & $\vee$ \\
\hline Khairiah & 95 & $\vee$ \\
\hline Sumarli & 92,5 & $\vee$ \\
\hline
\end{tabular}

Keterangan : $\vee:$ Tercapai;

- : Tidak tercapai

\section{Refleksi}

Berdasarkan Tabel 4 diketahui bahwa dari pelaksanaan tindakan siklus II, dapat diambil refleksi bahwa $100 \%$ guru MAN 1 Marabahan sudah dapat membuat RPP dengan baik, kriteria baik disini berarti penyusunan RPP guru yang bersangkutan telah mencapai rentang nilai 76 - 90, bahkan $40 \%$ diantaranya telah mampu mencapai rentang nilai $91-100$.

Dengan data yang didapat seperti diuraikan di atas, tindakan siklus II telah mampu meningkatkan kemampuan guru dalam menyusun RPP, sehingga 100\% guru MAN 1 Marabahan (10 orang) dapat mencapai rentang nilai minimal 76 - 90 dan atau rentang nilai 91 - 100 pada pembuatan RPP.

\section{B. Pembahasan}

Data yang diperoleh dan telah diuraikan di atas dapat dibuat secara singkat dapat dilihat pada Tabel 5 berikut: siklus I hanya $80 \%$ guru yang mampu mencapai rentang nilai $76-91$ atau dengan huruf mendapat nilai B, sedangkan pada siklus II, $100 \%$ guru telah berhasil mencapai kriteria keberhasilan penyusunan RPP, bahkan $40 \%$ diantaranya berhasil mencapai rentang nilai 91 - 100, atau dengan huruf mendapat nilai A. Data pada Tabel 5 tersebut dapat tergambar dengan jelas pada Gambar 1 berikut :

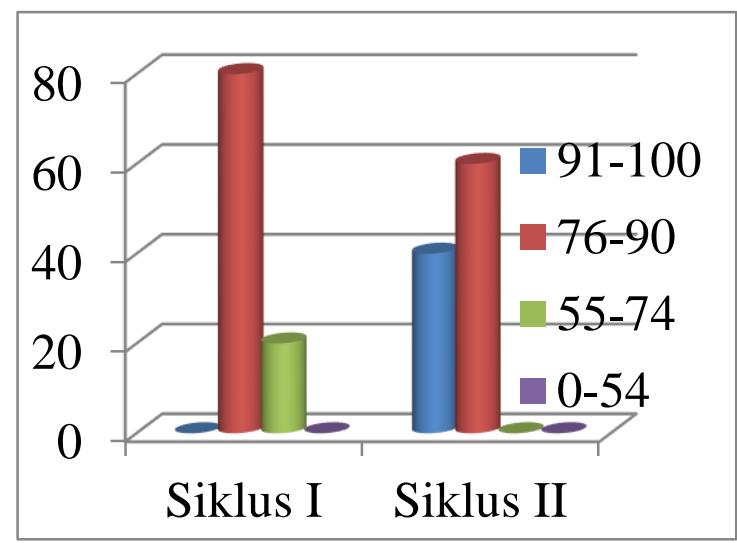

\section{Gambar 1. Peningkatan Persentase Pencapaian Rentang Nilai Keberhasilan}

Gambar 1 menunjukkan dengan jelas peningkatan yang terjadi dari siklus I ke siklus II. Dari data tersebut dapat dinyatakan bahwa hipotesis penelitian ini yang menyatakan bahwa "supervise akademik dapat meningkatkan kemampuan guru dalam menyusun Rencana Pelaksanaan Pembelajaran (RPP)" dapat diterima.

Tabel 5. Hasil Pelaksanaan Tindakan Tiap Siklus

\begin{tabular}{ccccccc}
\hline \multirow{2}{*}{ No. } & \multirow{2}{*}{ Rentang } & Nilai & \multicolumn{3}{c}{ Hasil Penilaian RPP } & \multirow{2}{*}{ Kriteria } \\
\cline { 3 - 6 } & & \multicolumn{2}{c}{ Siklus I } & \multicolumn{2}{c}{ Siklus II } & Keberhasilan \\
\cline { 2 - 6 } & & Frekuensi & $\%$ & Frekuensi & $\%$ & A \\
\hline 1. & $91-100$ & - & 80 & 6 & 40 & B \\
2. & $76-90$ & 8 & 20 & - & 60 & C \\
3. & $55-75$ & 2 & - & - & - & D \\
4. & $0-54$ & - & 100 & 10 & 100 & \\
\hline & Jumlah & 10 & 100 & & \\
\hline
\end{tabular}

Data pada Tabel 5 menunjukkan peningkatan dalam persentase jumlah guru yang berhasil mencapai kriteria keberhasilan penyusunan RPP. Pada

\section{PENUTUP}

Supervisi akademik dapat meningkatkan kemampuan guru dalam menyusun Rencana Pelaksanaan 
pembelajaran (RPP). Hal ini dibuktikan dengan peningkatkan persentase guru yang berhasil mencapai indikator keberhasilan kinerja dari $80 \%$ pada siklus I, menjadi $100 \%$ pada siklus II. Sebesar $40 \%$ diantaranya berhasil mencapai rentang nilai 91-100 (nilai A).

\section{DAFTAR PUSTAKA}

Aqib, Zainal. 2009. Penelitian Tindakan Sekolah untuk Pengawas Sekolah, Kepala Sekolah dan Guru, Bandung: Yrama Widya.

Depdiknas. 2007a. Materi Sosialisasi dan Pelatihan Kurikulum Tingkat Satuan Pendidikan (KTSP. Jakarta: Direktorat Jenderal Pendidikan Dasar dan Menengah.

Kemdiknas. 2010a. Penelitian Tindakan Sekolah - Materi Pelatihan Penguatan Kemampuan Kepala Sekolah. Jakarta: Direktorat Tenaga Kependidikan (Dirjen PPMPTK). 2010b. Supervisi Akademik Materi Pelatihan Penguatan Kemampuan Kepala Sekolah. Jakarta: Direktorat Tenaga Kependidikan (Dirjen PMPTK).

Riduan, M. 2017. Upaya Meningkatkan Kemampuan Guru Pendidikan Agama Islam dalam Penggunaan Media Pembelajaran Melalui Supervisi Akademik di SMP Negeri 3 Marabahan. Jurnal PTK dan Pendidikan. Vol (3) No 1: 41-50.

Rusman. 2013, Seri Manajemen Sekolah Bermutu Model-model Pembelajaran (Mengembangkan Profesionalisme Guru). Edisi kedua. Jakarta : PT. Grafiindo Persada. 
Jurnal PTK dan Pendidikan

Vol. 3 No. 2. Juli - Desember 2017 (11-18) 